\title{
Large-river dominated black carbon flux and budget: A case study of the estuarine-inner shelf of East China Sea, China
}

\author{
Yin Fang ${ }^{\mathrm{a}}$, Yingjun Chen ${ }^{\mathrm{a}, \mathrm{b}, *}$, Limin $\mathrm{Hu}^{\mathrm{c}}{ }^{\mathrm{C}}$, Chongguo Tian ${ }^{\mathrm{d}}$, Yongming Luo ${ }^{\mathrm{d}}$, Jun $\mathrm{Li}^{\mathrm{e}}$, Gan Zhang ${ }^{\mathrm{e}}$, \\ Mei Zheng ${ }^{\mathrm{f}}$, Tian Lin ${ }^{\mathrm{g}, * *}$ \\ ${ }^{a}$ Key Laboratory of Cities' Mitigation and Adaptation to Climate Change in Shanghai, College of Environmental Science and Engineering, Tongji University, Shanghai 200092, China \\ b Shanghai Institute of Pollution Control and Ecological Security, Shanghai 200092, China \\ ' Key Laboratory of Marine Sedimentology and Environmental Geology, First Institute of Oceanography, State Oceanic Administration, Qingdao 266061, China \\ d Key Laboratory of Coastal Environmental Processes and Ecological Remediation, Yantai Institute of Coastal Zone Research, Chinese Academy of Sciences, Yantai, 264003, China \\ e State Key Laboratory of Organic Geochemistry, Guangzhou Institute of Geochemistry, Chinese Academy of Sciences, Guangzhou 510640, China \\ ${ }^{\mathrm{f}}$ SKL-ESPC and BIC-EAST, College of Environmental Sciences and Engineering, Peking University, Beijing 100871, China \\ ${ }^{\mathrm{g}}$ State Key Laboratory of Environmental Geochemistry, Guiyang Institute of Geochemistry, Chinese Academy of Sciences, Guivang 550081, China
}

\section{H I G H L I G H T S}

- A preliminary BC budget in the coastal ECS was constrained.

- The Yangtze River alone contributed $\sim 72 \%$ of total BC flux into the coastal ECS.

- The coastal ECS could serve as a major sink of land-based BC

- Char and soot exhibited different geochemical behaviors in the coastal ECS.

\section{A R T I C L E I N F O}

\section{Article history:}

Received 26 July 2018

Received in revised form 8 October 2018

Accepted 11 October 2018

Available online 13 October 2018

Editor: Ashantha Goonetilleke

\section{Keywords:}

Carbon cycle

Black carbon

Riverine discharge

Yangtze River

East China Sea

\section{G R A P H ICA L A B S T RACT}

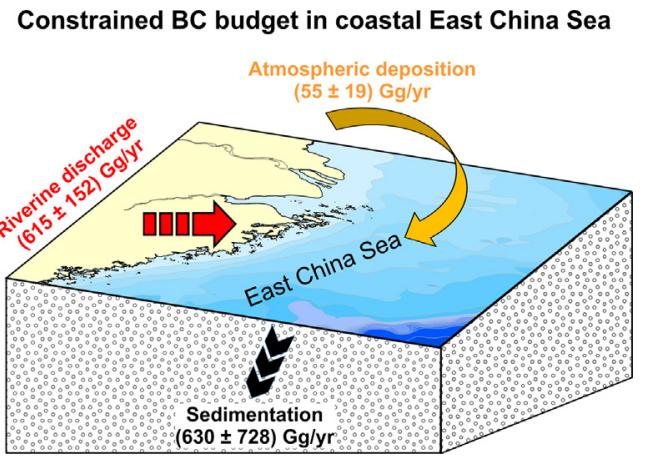

\begin{abstract}
A B S T R A C T
Mobilization of terrestrial-derived and recalcitrant black carbon (BC), including char and soot, from land to ocean exerts a significant influence on the global carbon cycle. This study elaborated the occurrence and spatial distributions of BC, char, and soot concentrations, as well as their burial fluxes, in the estuarine-inner shelf surface sediments of the East China Sea (ECS), an epicontinental sea adjacent to Chinese high-intensity BC emission source regions. Using a combination of $\mathrm{BC}$ measurements in the Yangtze River water and coastal ECS aerosol samples, a preliminary $\mathrm{BC}$ budget was concurrently constrained. The spatial distribution of char concentrations resembled largely that of $\mathrm{BC}$, but differed significantly from that of soot, indicating that char and soot exhibited different geochemical behaviors. In contrast to concentrations, BC, char, and soot burial fluxes exhibited highly consistent spatial patterns, and all declined as the distance from the coastline increased. For the coastal ECS, riverine discharge dominated $(\sim 92 \%)$ the total BC input, with the Yangtze River alone accounting for as high as $\sim 72 \%$. The areaintegrated sedimentary BC sink flux $(630 \pm 728 \mathrm{Gg} / \mathrm{yr})$ in the coastal ECS was equivalent to the total BC influx $(670 \pm 153 \mathrm{Gg} / \mathrm{yr})$, which coincided well with the regional sediment budget. This suggested that the terrestrial-derived and recalcitrant BC could be regarded as an alternative geochemical proxy for tracing the sediment source-to-sink processes in this region. Comparisons between BC and co-generated polycyclic aromatic
\end{abstract}

\footnotetext{
* Correspondence to: Y. Chen, College of Environmental Science and Engineering, Tongji University, Shanghai 200092, China.

** Corresponding author.

E-mail addresses: yjchentj@tongji.edu.cn (Y. Chen), lintian@vip.gyig.ac.cn (T. Lin).
} 
hydrocarbons (PAHs) budgets in the coastal ECS revealed similarities in their input pathways, but dramatic differences in their ultimate fates. Despite these, the ECS estuarine-inner shelf could serve as a major sink of these terrestrial-based materials in the global ocean.

(c) 2018 Published by Elsevier B.V.

\section{Introduction}

Black carbon (BC) is defined as the aromatic carbonaceous byproduct generated from incomplete biomass burning or fossil fuels combustion (Coppola et al., 2018; Fang et al., 2018). It has recently received substantial attention due to its widely recognized key roles in a variety of biogeochemical processes, including regional and global carbon cycle, climate change, air quality, and public health (Ramanathan and Carmichael, 2008; Anenberg et al., 2012; Bird et al., 2015; Fang et al., 2015). Despite these potential implications, BC is currently not a well-characterized chemical component, but is rather a complex combustion/temperature continuum (Masiello, 2004; Hammes et al., 2007). Overall, BC can be produced by two different chemical mechanisms, which yield two subtypes, i.e., char and soot (Han et al., 2011). Char is the solid residue formed by low temperature thermal treatment $\left(300-600{ }^{\circ} \mathrm{C}\right)$, while soot is the condensate produced from the vaporphase condensation reactions at high temperatures ( $600{ }^{\circ} \mathrm{C}$ ) (Elmquist et al., 2008; Han et al., 2011). Differences in the physical (e.g., the particle sizes) and chemical (e.g., the aromaticity) properties between char and soot result in their differential geochemical behaviors (Han et al., 2011; Han et al., 2015a; Han et al., 2015b). For instance, Han et al. (2015a) recently found an association of polycyclic aromatic hydrocarbons (PAHs) that is stronger with soot than with char, in the soils and sediments. Extensive combustion activities, coupled with its recalcitrance to chemical and/or biological degradation, render $\mathrm{BC}$ a ubiquitous component in the environment, such as in the atmosphere, soils, fresh/sea water, polar/alpine ice and snow, as well as lacustrine/ marine sediments (Bird et al., 2015; Coppola et al., 2018). It is extensively acknowledged that marine sediments are the final sinks for terrestrial-based BC through riverine run-off and atmospheric deposition (Elmquist et al., 2008; Sánchez-García et al., 2012; Fang et al., 2015; Yang and Guo, 2018).

A rough estimation based on extremely sparse data has concluded that up to $90 \%$ of global sedimentary BC sequestration occurs in the coastal shelf regime, although that area makes up only $\sim 10 \%$ of the global ocean (Suman et al., 1997). To consolidate this preliminary viewpoint, recently increasing efforts have been devoted to study the BC burial in these coastal shelf regimes. Most of these pioneering investigations are geographically confined within American and European coastal shelf areas, such as the Gulf of Maine (Gustafsson and Gschwend, 1998; Flores-Cervantes et al., 2009), Washington Coast (Dickens et al., 2004), Northern European Shelf (Sánchez-García et al., 2012), Gulf of Cádiz (Sánchez-García et al., 2013), and Pan-Arctic Shelves (Guo et al., 2004; Elmquist et al., 2008; Yang and Guo, 2018). However, only little attention has been paid to the Asian coastal shelves (Fang et al., 2015; Hu et al., 2016; Huang et al., 2016), where BC emissions from Asian continent are estimated to contribute more than half of the global anthropogenic BC emissions (Bond et al., 2004). This implies that a more detailed study of $\mathrm{BC}$ in the coastal shelf of Asian countries, especially in the largest BC emitter of China (Wang et al., 2012), will to a large extent deepen our understanding of the influence of sedimentary BC sink on the regional and even global carbon cycles and budgets.

The East China Sea (ECS) is a typical epicontinental sea of the northwest Pacific Ocean and has one of the largest coastal shelves in the world (Zhang et al., 2017). The areas adjacent to ECS are among the most heavily populated and highly industrialized and urbanized regions in China (Lin et al., 2013; Liu et al., 2017a). The ECS is strongly influenced by several major Chinese rivers, including the dominant Yangtze River, as well as other local rivers (e.g., Qiantang, Ou, and Min Rivers) along the eastern coasts of Zhejiang and Fujian provinces (Hu et al., 2011; Lin et al., 2013). The Yangtze River, the longest $(\sim 6300 \mathrm{~km})$ Asian river with a total drainage area of $\sim 1.94 \times 10^{6} \mathrm{~km}^{2}$, accounting for one-fifth of the Chinese territory, historically has the world's fourth largest sediment load and fifth largest freshwater discharges (Yang et al., 2006). It is unquestionable that large quantities of anthropogenic substances, like BC, will pour into the ECS via riverine discharge. In addition, the coastal ECS is located in the transport pathway of Asian continental outflow (Wang et al., 2015; Jiang et al., 2018), and there are several booming ports at the ECS coast (Liu et al., 2017b). As an example, the Shanghai Port and Ningbo-Zhoushan Port are now ports with the world's largest container throughput and cargo throughput, respectively. Such busy marine shipping activities in the ECS may also be significant sources of aerosol BC (Zhang et al., 2018). It is apparent that atmospheric deposition may also transport significant amounts of $\mathrm{BC}$ released from mainland China and sea-going ships (and fishing boats) to the ECS. Due to the net effects of shear forces from coastal currents (Bianchi and Allison, 2009), BC from atmospheric deposition and riverine discharge is preferentially trapped in the Yangtze River Estuary (YRE) and the inner shelf of the ECS, which are developed depocenters of fine-grained sediments (mainly clayey-silt particles) (Jia et al., 2018). Our recent investigations have demonstrated that the ECS estuarine-inner shelf sediments are important sinks for anthropogenic materials, such as the PAHs and heavy metals (e.g., mercury (Hg)) (Lin et al., 2013; Liu et al., 2017a). Therefore, the estuarine-inner shelf of the ECS is also expected to be a key sink for $\mathrm{BC}$, and is consequently ideal for studying the regional BC budgets or source-to-sink processes, given that the $\mathrm{BC}$ intensities of the adjoining areas are among the highest in China (Wang et al., 2012). To our knowledge, the available BC studies in the coastal ECS focused mainly on individual environmental compartments, such as aerosols (Cao et al., 2013; Chen et al., 2013; Andersson et al., 2015; Wang et al., 2015), soils (Lehndorff et al., 2014), waters (Wang et al., 2016; Xu et al., 2016), or sediments (Hung et al., 2011; Li et al., 2012; Huang et al., 2016). The lack of information on integrated BC flux for these media in this area significantly limits our understanding of the regional $\mathrm{BC}$ budgets or sourceto-sink processes.

The major objectives of this study are two-fold: (1) to detail the occurrence and spatial distributions of $\mathrm{BC}$ and the two subtypes char and soot concentrations and burial fluxes in surface sediments of the estuarine-inner shelf of the ECS; (2) to quantitatively constrain a preliminary $\mathrm{BC}$ budget in the coastal ECS, in combination with recent $\mathrm{BC}$ measurements of the Yangtze River water and coastal ECS aerosol samples (Cao et al., 2013; Wang et al., 2015; Huang et al., 2016).

\section{Materials and methods}

\subsection{Sediment sampling}

A total of 58 surface sediments $(0-3 \mathrm{~cm})$ from the Yangtze River estuarine-inner shelf of the ECS (Fig. 1) were collected, using a box corer of stainless steel in the cruises conducted by R/V Dong Fang Hong 2 and R/V Ke Yan 59 during 2011-2013. All sediment samples were packed in pre-combusted aluminum foil, and they were stored at $-20{ }^{\circ} \mathrm{C}$ until further analysis. 


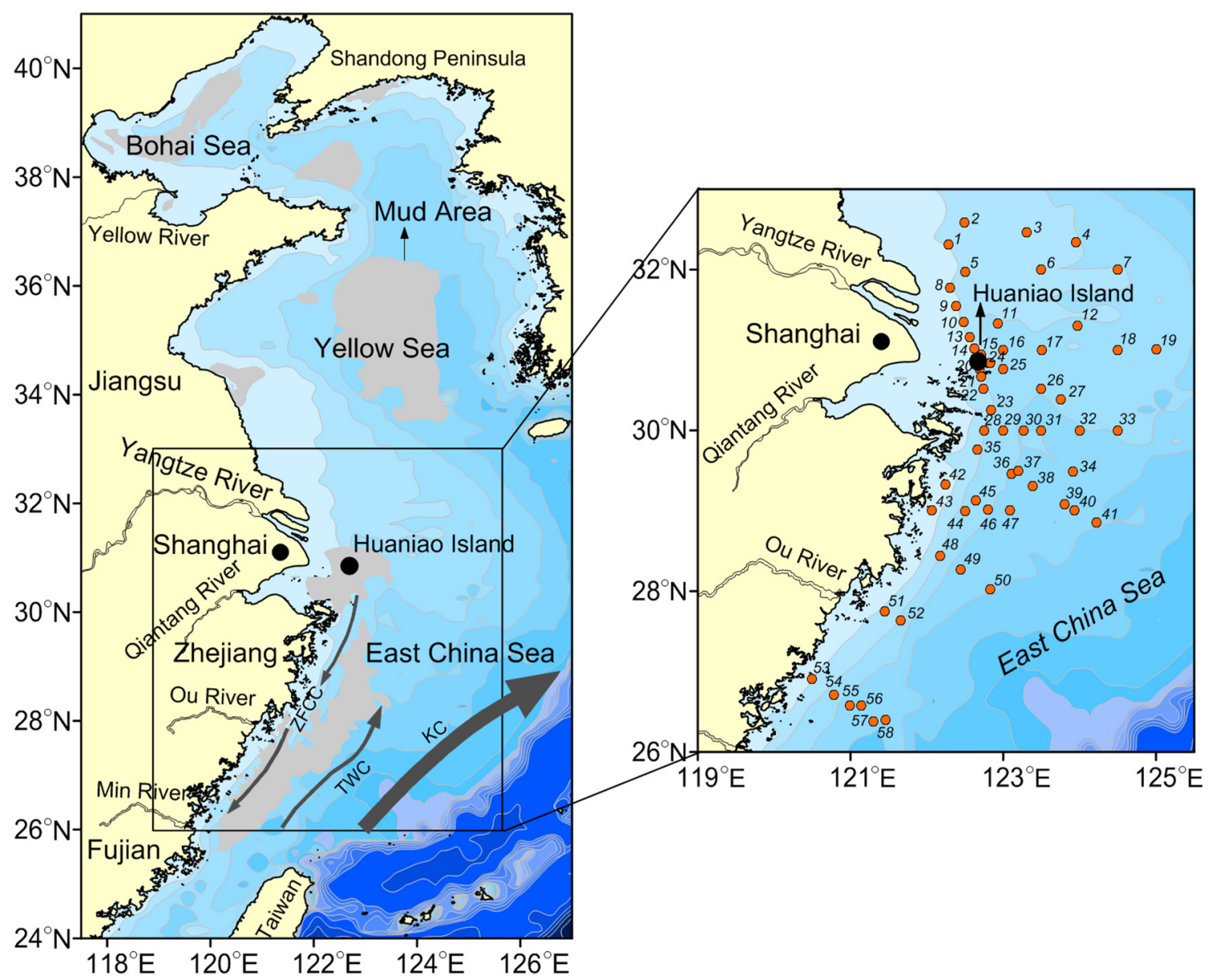

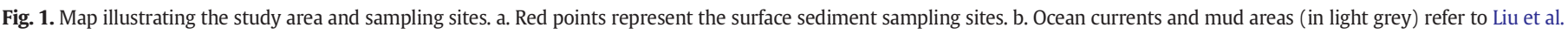

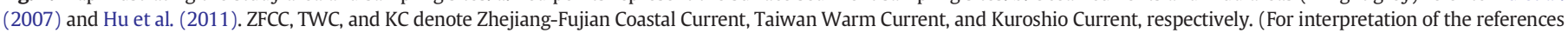
to colour in this figure legend, the reader is referred to the web version of this article.)

\subsection{BC, char, and soot quantification}

In the present study, wet-chemical pre-treatment coupled with thermal optical reflectance (TOR) detection was applied to quantify the sedimentary BC, owing to its proven ability for effectively differentiating between char and soot (Han et al., 2007a; Han et al., 2011; Han et al., 2012; Han et al., 2015b; Hu et al., 2016). In brief, thawed, freezedried, and ground sediments ( $<80$ meshes) were processed with hydrochloric and hydrofluoric acids $(\mathrm{HCl} / \mathrm{HF})$ to remove the inorganic materials, such as carbonates, silicates, and some metals and metallic oxides. The acid-treated sediment residues were diluted with Milli-Q water $(18.2 \mathrm{M} \Omega \cdot \mathrm{cm})$ and then filtered through pre-combusted $\left(450^{\circ} \mathrm{C}, 4 \mathrm{~h}\right.$ ) quartz fibre filters (Whatman, $47 \mathrm{~mm}$ diameter, nominal pore size $0.7 \mu \mathrm{m})$. The filters loaded with sediment residues were airdried and analyzed for BC on a Desert Research Institute (DRI) Thermal/Optical Carbon Analyzer (Model 2001A) following the protocol of Interagency Monitoring of Protected Visual Environment (IMPROVE) (Fang et al., 2015; Fang et al., 2018). A punch of $0.544 \mathrm{~cm}^{2}$ filter was delivered into an oven for carbon quantification. The oven was first heated in $100 \%$ He atmosphere, yielding four organic carbon subfractions in four different temperature steps. Then the analytical material was transferred to a mixed atmosphere of $98 \% \mathrm{He} / 2 \% \mathrm{O}_{2}$. Correspondingly, three $\mathrm{BC}$ subfractions ( $\mathrm{BC} 1, \mathrm{BC} 2$, and $\mathrm{BC} 3$ ) were produced in three temperature steps $\left(580,740\right.$, and $\left.840^{\circ} \mathrm{C}\right)$. Pyrolysis of organic carbon (defined as $\mathrm{OC}_{\text {Pyro }}$ ) occurred concurrently in the pure He atmosphere, as seen from the declined reflectance signal of the laser. $\mathrm{OC}_{\mathrm{Pyro}}$, like the original $\mathrm{BC}$ fraction, was oxidized in the second $\mathrm{He} / \mathrm{O}_{2}$ stage. The IMPROVE protocol calculated $\mathrm{BC}$ as the sum of three $\mathrm{BC}$ subfractions minus the $\mathrm{OC}_{\text {Pyro }}$ (i.e., $\mathrm{BC}=\mathrm{BC} 1+\mathrm{BC} 2+\mathrm{BC} 3-\mathrm{OC}_{\text {Pyro }}$ ). Han et al. (2007a) further examined the thermograms of seven char and three soot reference materials following the same protocol as in the present study, and they observed that char evolved almost exclusively in the BC1 step and soot in the $\mathrm{BC} 2+\mathrm{BC} 3$ steps. Therefore, in this study char was defined as $\mathrm{BC} 1$ $-\mathrm{OC}_{\text {Pyro }}$, and soot as $\mathrm{BC} 2+\mathrm{BC}$. The detailed procedures regarding the sedimentary $\mathrm{BC}$, char, and soot separation and quantification are described in our recent work (Fang et al., 2015; Hu et al., 2016).

\subsection{Quality assurance and quality control $(Q A / Q C)$}

Initially, we checked whether the acid-treated sediment residues onto the filters have even distributions (Khan et al., 2009; Han et al., 2011; Fang et al., 2015; Hu et al., 2016). For this, $10 \%$ of the total filters $(n=6)$ were randomly selected, and two punches drilled from different locations in a filter were analyzed for BC. The relative standard deviation (RSD, \%) of BC concentrations from the two punches was 2-9\%, and averaged $<5 \%$, implying even distributions of the sediment residues onto the filters. In addition, blanks, replicates, and standard reference material (NIST SRM-1941b, marine sediments from the Chesapeake Bay), were also examined. The blanks $(n=6)$ contained non-detectable BC contents. The RSD of 6 pairs of replicates was $2-11 \%$, and averaged within $6 \%$. The BC content in the NIST SRM-1941b was $10.89 \pm$ $1.01 \mathrm{mg} / \mathrm{g}$ ( $n=6$; all weights are dry weight), which agreed well with the values reported by recent studies with a similar TOR method (Hammes et al., 2007; Han et al., 2007b; Cong et al., 2013; Fang et al., 
2015; Hu et al., 2016). The QA/QC results evidenced that the applied BC methodology was credible and reproducible.

\section{Results and discussion}

3.1. Occurrence and spatial distributions of $B C$, char, and soot concentrations

$\mathrm{BC}$ was detected in all estuarine-inner shelf surface sediments of the ECS, and its concentration varied by a factor of 6 , ranging from 0.33 to $2.04 \mathrm{mg} / \mathrm{g}$ and averaging $1.04 \pm 0.40 \mathrm{mg} / \mathrm{g}$ (Supporting information (SI) Table S1). For the two subtypes, char and soot had concentration ranges of $0.17-1.89$ and $0.13-0.52 \mathrm{mg} / \mathrm{g}$, with averages of $0.79 \pm 0.40$ and $0.25 \pm 0.07 \mathrm{mg} / \mathrm{g}$, respectively (SI Table S1).

Fig. 2a-c shows the spatial distributions of BC, char, and soot concentrations. Generally, there were two remarkable spatial features observed for BC concentrations. One was the relatively low level $(<0.90 \mathrm{mg} / \mathrm{g}$ ) occurring in the YRE, and the other was the apparent decreasing trend from the inshore areas $(>1.80 \mathrm{mg} / \mathrm{g})$ toward the outer shelf $(\sim 0.60 \mathrm{mg} / \mathrm{g})$ along the Zhejiang-Fujian coastal shelf areas. Consistent with the present terrestrially combustion-derived $\mathrm{BC}$, our recent work has also found relatively low concentrations of other terrestrialderived materials, such as PAHs and heavy metal of Hg, in the YRE (Lin et al., 2013; Liu et al., 2017a). The strong dilution effect induced by the overwhelmingly high sedimentation rates in the YRE might to a large extent resulted in the low levels of these land-based materials. It has been estimated that $40 \%$ of the Yangtze River-derived sediments was deposited in the YRE subaqueous delta (Demaster et al., 1985), and the measured sedimentation rates there could reach $>4 \mathrm{~cm} / \mathrm{yr}$, which was at least 3 times higher than those in the Zhejiang-Fujian coastal shelf areas (Liu et al., 2006; Jia et al., 2018).
The spatial distribution of char concentrations resembled largely that of BC. Since char constituted a major component of BC, with an average char/BC ratio of $72 \pm 12 \%$ (SI Table S1), the similar spatial distributions between char and $\mathrm{BC}$ concentrations should not be unexpected. However, the spatial distribution of soot concentrations differed considerably from those of $\mathrm{BC}$ and char. The soot concentrations increased seaward with increasing distance from the coastline in the Zhejiang-Fujian coastal shelf areas. The dramatically different spatial patterns between char and soot indicated that they had different geochemical behaviors in this regime. Specifically, the spatial distribution of char corresponded well with the fine-grained sediment distributions within the coastal mud of the ECS inner shelf (Zhu et al., 2011). This implied that the sedimentary dynamics exerted a predominant effect on the fate of char in this area, as the mud deposits here are driven by the seasonal changes of riverine inputs, estuarine processes, tidal currents, shelf circulations, and storm/typhoon episodes (Liu et al., 2007). The Yangtze River-derived fine-grained sediments are transported southward along the inner self in the bottom layers by the intensified coastal currents $(\sim 50 \mathrm{~cm} / \mathrm{s})$ during the wintertime (Bian et al., 2013). The offshore region in the coastal ECS is characterized as a bypass zone with little net accumulation due to the limited sediment supply associated with the strong winnowing (Zhu et al., 2011). Therefore, the high occurrence of soot in the offshore region could be largely related to its input pathway, mainly by atmospheric deposition, which can mobilize the submicron-meter sized soot particles more effectively (Han et al., 2015b).

\subsection{Occurrence and spatial distributions of $B C$, char, and soot burial fluxes}

Compared with the sedimentary concentration, which may be strongly influenced by the varying inflows of organic and mineral

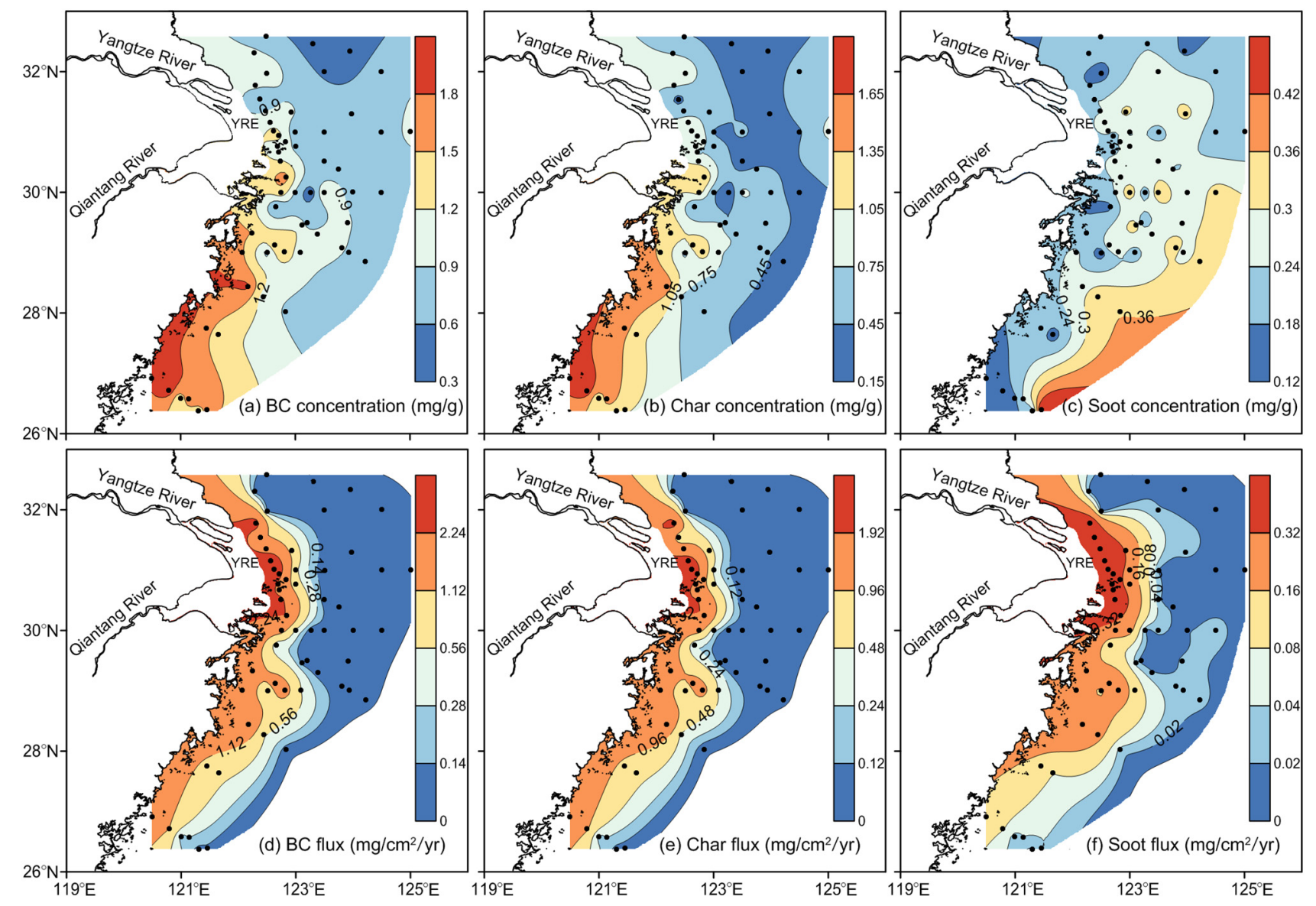

Fig. 2. Spatial distributions of BC, char, and soot concentrations and burial fluxes in the estuarine-inner shelf surface sediments of the ECS. 
materials, the geochemical parameter of the burial flux was more favorable for reflecting their real sedimentation (Fang et al., 2015; Xu et al., 2017). The calculation processes of BC, char, and soot burial fluxes are described in SI Text S1. The ranges of BC, char, and soot burial fluxes were $0.03-3.52,0.01-2.79$, and $0.01-0.75 \mathrm{mg} / \mathrm{cm}^{2} / \mathrm{yr}$, with mean values of $0.79 \pm 0.91,0.62 \pm 0.74$, and $0.16 \pm 0.19 \mathrm{mg} / \mathrm{cm}^{2} / \mathrm{yr}$, respectively (the standard deviations following averages were calculated from the total analyzed 58 individual sedimentary BC, char, and soot burial flux in the coastal ECS region; SI Table S1). It was apparent that, regardless of $\mathrm{BC}$ and the two subtypes, the variations of their burial fluxes (by factors of 75-279) were more pronounced than those of their corresponding concentrations (by factors of 4-11), which was mainly ascribed to the significant difference in the sedimentation rates in the study area.

In contrast to those concentrations, the spatial distributions of $\mathrm{BC}$, char, and soot burial fluxes exhibited highly consistent patterns (Fig. 2d-f). The BC, char, and soot burial fluxes all decreased with increasing distance from the coastline, and their maximum fluxes all occurred in the YRE. A similar seaward decreasing trend of BC burial flux has been also detected in other large-river impacted estuaries, such as the Yellow River estuary in the Bohai Sea (Fig. 1), in which the BC burial flux decreased significantly from $\sim 1.10$ to $\sim 0.20 \mathrm{mg} / \mathrm{cm}^{2} / \mathrm{yr}$ within $\sim 60 \mathrm{~km}$ away from the coastline (Fang et al., 2015). The spatial distributions of BC, char, and soot burial fluxes correlated well with those for sedimentation rates (Liu et al., 2006; Jia et al., 2018). For the estuarine-inner shelf of the ECS, the spatial distribution of the sedimentation rates was mainly dominated by the Yangtze River discharged sediments. Therefore, it could be expected that riverine discharge, especially from the large Yangtze River, might be the major source of BC (especially for char) to the ECS estuarine-inner shelf areas. This hypothesis was evidently confirmed from the following constrained regional BC budget calculations in the coastal ECS (see Section 3.3).

The mean BC burial flux in the estuarine-inner shelf of the ECS $(0.79$ $\pm 0.91 \mathrm{mg} / \mathrm{cm}^{2} / \mathrm{yr}$ ) was 2 to 6 times higher than those obtained in the Bohai and Yellow Seas, China $\left(0.17 \pm 0.20 \mathrm{mg} / \mathrm{cm}^{2} / \mathrm{yr}\right.$ ) (Fang et al., 2015), Gulf of Maine, USA $\left(0.13 \pm 0.04 \mathrm{mg} / \mathrm{cm}^{2} / \mathrm{yr}\right.$ ) (Gustafsson and Gschwend, 1998), Coast of Pakistan $\left(0.33 \pm 0.16 \mathrm{mg} / \mathrm{cm}^{2} / \mathrm{yr}\right.$ ) (Ali et al., 2014), and Gulf of Thailand $\left(0.21 \pm 0.23 \mathrm{mg} / \mathrm{cm}^{2} / \mathrm{yr}\right.$ ) (Hu et al., 2016), but it was nearly a half that in the strong human impact Swedish Continental Shelf $\left(1.10 \mathrm{mg} / \mathrm{cm}^{2} / \mathrm{yr}\right)$ (Sánchez-García et al., 2012). Here it should be noted that, in addition to the distinct human activities among these coastal regions, the applied BC quantification method was also a key factor complicating the above flux comparisons. For instance, Sánchez-García et al. (2013) compared the chemical thermal oxidation (CTO-375) and benzene polycarboxylic acids (BPCAs) derived BC burial fluxes in the Gulf of Cádiz, Spain, and found that the CTO375 -derived BC burial flux $\left(0.12 \pm 0.08 \mathrm{mg} / \mathrm{cm}^{2} / \mathrm{yr}\right)$ was only one half that of the BPCAs-based $\left(0.25 \pm 0.21 \mathrm{mg} / \mathrm{cm}^{2} / \mathrm{yr}\right)$. Despite the large methodological uncertainties and a discrepancy of nearly an order of magnitude observed among these typical coastal shelf regimes, the BC burial fluxes there were still 2 to 4 orders of magnitude larger than those in the pelagic regimes, such as $0.002 \mathrm{mg} / \mathrm{cm}^{2} / \mathrm{yr}$ for the South Atlantic Ocean (Lohmann et al., 2009) and $0.0001 \mathrm{mg} / \mathrm{cm}^{2} / \mathrm{yr}$ for the Pacific Ocean (Smith et al., 1973). Such low burial fluxes of BC in the open/deep ocean sediments were largely resulted from their extraordinarily low sedimentation rate (generally $<0.01 \mathrm{~cm} / \mathrm{yr}$ ), which was a crucial parameter for the calculation of the burial flux. The occurrence of the predominant $\mathrm{BC}$ sequestration at the coastal shelf regimes suggest us that in future we should pay closer and on-going attention on these regimes, such as the extensive East China Marginal Seas (Fig. 1) and the Arctic (the world's largest coastal shelf system) (Sánchez-García et al., 2012).

The area-integrated sedimentary BC sink flux was calculated by multiplying the mean $\mathrm{BC}$ burial flux in a given region by the area of that region. It is estimated that $630 \pm 728 \mathrm{Gg} / \mathrm{yr}$ of $\mathrm{BC}$ was sequestrated in the estuarine-inner shelf surface sediments of the ECS, over an area of $\sim 0.8$ $\times 10^{5} \mathrm{~km}^{2}$. Until now, there have been several investigations reporting the sedimentary BC sink flux in the geographically separated coastal regions, such as $\sim 200 \mathrm{Gg} / \mathrm{yr}$ in the Gulf of Thailand $\left(\sim 1.5 \times 10^{5} \mathrm{~km}^{2}\right)$ (Hu et al., 2016), 400-800 Gg/yr in the New England shelf off the Northeastern USA $\left(\sim 3.8 \times 10^{5} \mathrm{~km}^{2}\right)$ (Gustafsson and Gschwend, 1998), $\sim 1160 \mathrm{Gg} / \mathrm{yr}$ in the entire Northern European Shelf $\left(\sim 1.0 \times 10^{6} \mathrm{~km}^{2}\right)$ (Sánchez-García et al., 2012), and $3050 \mathrm{Gg} / \mathrm{yr}$ in the three Arctic Shelves $\left(\sim 1.4 \times 10^{6} \mathrm{~km}^{2}\right.$, including Mackenzie, Chukchi, and Bering Shelves) (Yang and Guo, 2018). It is obvious that the coastal shelf sediments are likely to be significant final $\mathrm{BC}$ reservoirs in the global $\mathrm{BC}$ biogeochemical cycles, which may transfer carbon from the rapid-cycling bio-atmospheric carbon cycle into the slow-cycling geological carbon cycle (Fang et al., 2015).

\subsection{A preliminary constrained $B C$ budget in the estuarine-inner shelf of the} ECS

To constrain the BC budget in the estuarine-inner shelf of the ECS, a primary step is to calculate each process-based BC flux. In addition to above presented sedimentation (corresponding to the area-integrated sedimentary BC sink flux), other major processes involved in the coastal ECS shelf $B C$ budget calculations consist of atmospheric deposition and riverine discharge. The detailed procedures for calculations of the $\mathrm{BC}$ fluxes from atmospheric deposition and riverine discharge were elaborated in SI Texts S2 and S3, respectively.

The preliminary constrained $\mathrm{BC}$ budget in the estuarine-inner shelf of the ECS is shown in Fig. 3. The total BC influx to the coastal ECS was estimated at $670 \pm 153 \mathrm{Gg} / \mathrm{yr}$ (the sum of atmospheric deposition and riverine discharge) (Texts S2 and S3). For atmospheric deposition, including both dry and wet depositions, a total of $55 \pm 19 \mathrm{Gg} / \mathrm{yr}$ of BC was deposited into the coastal ECS over an area of $\sim 0.8 \times 10^{5} \mathrm{~km}^{2}$, which accounted for only $~ 8 \%$ of the total influx. Of the total atmospheric deposition, dry and wet depositions each contributed $14 \pm 6$ and $41 \pm 18 \mathrm{Gg} / \mathrm{yr}$, with a regional dry/wet deposition ratio of $\sim 0.34$, $\sim 1.7$-fold that of the global ocean average BC dry/wet deposition ratio $(\sim 0.2)$ (Jurado et al., 2008). For the riverine discharge, $615 \pm$ $152 \mathrm{Gg} / \mathrm{yr}$ of BC was delivered into the coastal ECS, which was $>11$ times higher than that from the atmospheric deposition. Therefore, it can be concluded that, in the coastal ECS, the riverine discharge was the predominant $\mathrm{BC}$ input pathway, accounting for $~ 92 \%$ of the total influx. According to the riverine BC flux estimations (SI Text S3), the Yangtze River and other local rivers from adjacent provinces (including Zhejiang, Fujian, and Taiwan, Fig. 1) discharged $485 \pm 147$ and $130 \pm$ $40 \mathrm{Gg} / \mathrm{yr}$ of $\mathrm{BC}$, respectively, with the Yangtze River alone contributing up to $\sim 80 \%$ of the total river influx. Furthermore, our most concerned Yangtze River alone also accounted for up to $72 \%$ of the total BC influx to the coastal ECS. This to a large degree implied that BC produced within the Yangtze River drainage basin and then discharged by the

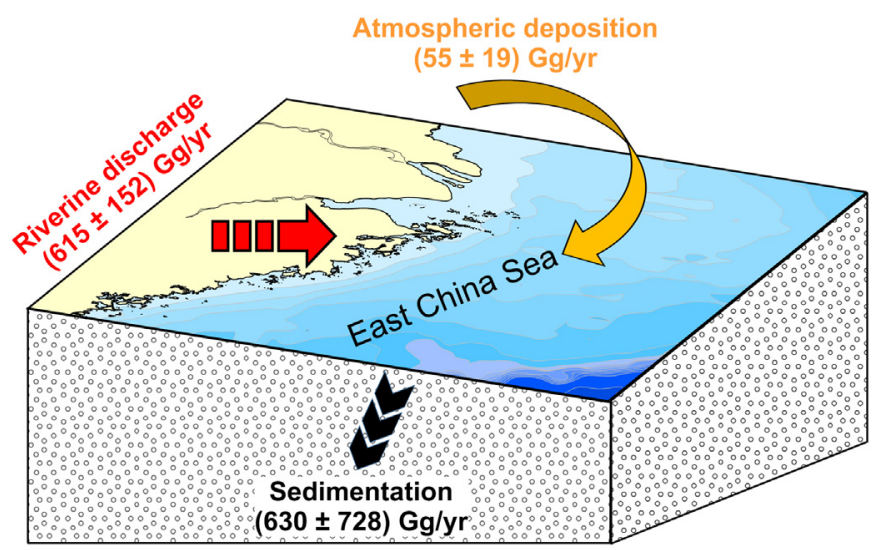

Fig. 3. A preliminary constrained $\mathrm{BC}$ budget in the estuarine-inner shelf of the ECS. 
Yangtze River exerted a far-reaching influence on the regional BC cycle in the coastal ECS shelf marine ecosystem.

Coincidently, we found that the annual sedimentary BC burial $(\sim 630 \mathrm{Gg} / \mathrm{yr}$ ) was nearly equivalent to the estimated total BC flux into the coastal ECS $(\sim 670 \mathrm{Gg} / \mathrm{yr})$. This suggested that the regional BC from the atmospheric and riverine delivery was almost ( $94 \%)$ sequestrated in the ECS estuarine-inner shelf. The BC budget pattern in the coastal ECS was well in accordance with the established regional sediment budget patterns by some researchers (Deng et al., 2006; Jia et al., 2018). For instance, Deng et al. (2006) estimated that the annual sediment flux in the coastal ECS shelf accounted for $~ 96 \%$ of the total terrestrial inputs (mainly from riverine discharge, with negligible contribution from atmospheric deposition), and there was only $<4 \%$ of total sediments escaping off the ECS and entering to the northwest Pacific Ocean. Such high retention potential of sediments and associated BC in this area were mainly attributed to the broad nature of the ECS shelf edge (approximately 500-600 km), together with an alongshore sediment transport driven by the southward Zhejiang-Fujian Coastal Current (ZFCC), and an obstruction of the cross-shelf seaward transport by the year-round northward Taiwan Warm Current (TWC) (Fig. 1) (Deng et al., 2006). The highly consistent budget patterns between BC and sediments in coastal ECS shelf indicated that the terrestrial-derived and recalcitrant BC component could be regarded as an alternative geochemical proxy for tracing the sediment source-to-sink processes in this region.

PAHs are a class of organic molecular proxies co-generated with BC during the incomplete combustion of organic matter (Fang et al., 2016). The similar production mechanism shared by BC and PAHs makes it reasonable to compare their budgets. The PAHs budget in the coastal ECS showed that, as for the input pathways, atmospheric deposition and riverine discharge accounted for $\sim 7 \%$ ( $17 \mathrm{t} / \mathrm{yr}$ over an area of $\left.\sim 0.8 \times 10^{5} \mathrm{~km}^{2}\right)$ and $\sim 93 \%(\sim 243 \mathrm{t} / \mathrm{yr})$ of the total USEPA 16 priority PAHs influx, respectively (Lin et al., 2013; Jiang et al., 2018), which matched well with the present BC input patterns. Despite their similar input patterns, however, the ultimate retention of PAHs in the sediments ( $58 \%)$ was significantly lower than that of BC $(\sim 94 \%)$ (Lin et al., 2013; Jiang et al., 2018). The selective release of low molecular weight (LMW) PAHs, such as naphthalene, fluorine, and phenanthrene, from bottom sediments to overlying water due to the resuspension triggered by the strong winter East Asian monsoon has been demonstrated to be a key sedimentary PAHs loss process in this area (Lin et al., 2013). Because of their relatively high water solubility, the LMW PAHs are prone to be maintained in the water column, and they can thus be effectively uptaken by the abundant aquatic organisms or even liberated into the air (Lin et al., 2013). Our latest one-year study showed that in the coastal ECS, $44 \mathrm{t} / \mathrm{yr}$ of PAHs was net volatilized from seawater to atmosphere over an area of $\sim 0.8 \times 10^{5} \mathrm{~km}^{2}$, of which $\sim 90 \%$ was the LMW three-ring PAHs, suggesting that seawater acts as a second source of three-ring PAHs to the ambient atmosphere (Jiang et al., 2018).

Although the preliminary BC source-to-sink processes in the coastal ECS have been constrained, there were still some uncertainties associated with these $\mathrm{BC}$ budget calculations. These uncertainties derived mainly from the inconsistent time scales integrated in each environmental compartment, our lack of consideration of the spatio-temporal variability of BC concentrations in aerosol and river water samples, as well as the inconsistent $\mathrm{BC}$ quantification methods applied to the environmental samples. Also, the large uncertainty in the burial flux of $\mathrm{BC}$ makes the BC budget poorly constrained. All these sources of uncertainty imply that continuous field observations and consistent $\mathrm{BC}$ quantification methods are essential steps for approaching a more reliable BC budget construction (Fang et al., 2018). Regional BC budgets have also been investigated in some other coastal areas, such as the coastal Bohai Sea (Fang et al., 2015), New England continental shelf (Gustafsson and Gschwend, 1998), Gulf of Maine (Flores-Cervantes et al., 2009), and Northern European shelf (Sánchez-García et al., 2012). All these available studies revealed a significant "sink" of the coastal shelf sediments for the terrestrial BC burial. However, the input patterns of $\mathrm{BC}$ varied among these regions. Except for the coastal Bohai Sea, the $\mathrm{BC}$ budgets in the other three coastal regions all showed that the sedimentary $\mathrm{BC}$ sink fluxes were comparable to the upwind atmospheric BC emissions, illustrating the key role of atmospheric deposition over riverine discharge on the $\mathrm{BC}$ transport in these areas. For the coastal Bohai Sea (Fig. 1), which is also an important part of the East China Marginal Seas, the inputs of BC differed significantly from those in the coastal ECS. Atmospheric deposition and riverine discharge were of equal importance in delivering BC to the coastal Bohai Sea (Fang et al., 2015; Fang et al., 2018). The much higher percentage of BC from riverine discharge in the coastal ECS ( 93\%) than that in the coastal Bohai Sea $(\sim 50 \%)$ was primarily due to the overwhelmingly higher BC discharge from the Yangtze River $(\sim 485 \mathrm{Gg} / \mathrm{yr})$ than from the Yellow River $(\sim 70 \mathrm{Gg} / \mathrm{yr})$. However, considering the overall decreasing trend of freshwater and sediment discharges from both the Yellow River and Yangtze River owing to a number of large water and soil conservation engineering construction in recent decades (Yang et al., 2006; Wang et al., 2007), the importance of BC from atmospheric deposition in these coastal areas is expected to increase. Compared with riverine discharge, atmospheric transport is more efficient in accelerating the regional BC dispersal, particularly released from the world's largest BC emitter of China, into the global BC biogeochemical cycles.

\section{Conclusions}

BC concentrations in the ECS estuarine-inner shelf surface sediments varied from 0.33 to $2.04 \mathrm{mg} / \mathrm{g}$ and averaged $1.04 \pm 0.40 \mathrm{mg} / \mathrm{g}$. Char constituted a major fraction (on average $72 \pm 12 \%$ ) of BC. The spatial distribution of char concentrations resembled largely that of BC, but differed considerably from that of soot, indicating the different geochemical behaviors between char and soot in this region. In contrast, BC, char, and soot burial fluxes exhibited highly consistent spatial patterns and all declined with increasing distance from the coastline, which was mainly resulted from the dominant input from riverine discharge, especially from the dominant Yangtze River. The preliminary constrained BC budget in the coastal ECS showed that the riverine discharge contributed as high as $\sim 92 \%$ of the total BC inputs, and sequestration to bottom sediments (i.e., the area-integrated BC sink flux, $630 \pm 728 \mathrm{Gg} / \mathrm{yr}$ ) was nearly equivalent to the estimated total $\mathrm{BC}$ flux $(670 \pm 153 \mathrm{Gg} / \mathrm{yr})$ into the coastal ECS. Comparisons between BC and co-generated PAHs budgets in the coastal ECS revealed their similar input pathways but dramatically different ultimate fates. Despite these, the estuarine-inner shelf of the ECS could serve as a major sink for these terrestrial-based materials. This study also suggests that in future we should pay closer and on-going attention on the coastal shelf regimes because of the observed $\sim 2-4$ orders of magnitude larger BC burial flux occurring in these regimes than those in the pelagic regimes.

\section{Acknowledgments}

This work was financially supported by National Natural Science Foundation of China (Nos. 41703087, 91744203, 41473091, 41430646, and 41722603), Key Laboratory of Yangtze River Water Environment of Ministry of Education in Tongji University (No. YRWEF201802), Basic Scientific Fund for National Public Research Institutes of China (No. 2017S01), Key Laboratory of Coastal Environmental Processes and Ecological Remediation of YICCAS (No. 2016KFJJ04), and State Key Laboratory of Organic Geochemistry of GIGCAS (No. SKLOG-201620). The authors wish to thank the crew of R/V Dong Fang Hong 2 of Ocean University of China and R/V Ke Yan 59 for collecting the surface sediment samples.

\section{Appendix A. Supplementary data}

Supplementary data to this article can be found online at https://doi. org/10.1016/j.scitotenv.2018.10.156. 


\section{References}

Ali, U., Syed, J.H., Liu, J., Sánchez-García, L., Malik, R.N., Chaudhry, M.J.I., Arshad, M., Li, J., Zhang, G., Jones, K.C., 2014. Assessing the relationship and influence of black carbon on distribution status of organochlorines in the coastal sediments from Pakistan. Environ. Pollut. 190, 82-90

Andersson, A., Deng, J., Du, K., Zheng, M., Yan, C., Skold, M., Gustafsson, Ö., 2015. Regionally-varying combustion sources of the January 2013 severe haze events over Eastern China. Environ. Sci. Technol. 49, 2038-2043.

Anenberg, S.C., Schwartz, J., Shindell, D., Amann, M., Faluvegi, G., Klimont, Z., JanssensMaenhout, G., Pozzoli, L., Van Dingenen, R., Vignati, E., Emberson, L., Muller, N.Z., West, J.J., Williams, M., Demkine, V., Hicks, W.K., Kuylenstierna, J., Raes, F., Ramanathan, V., 2012. Global air quality and health co-benefits of mitigating nearterm climate change through methane and black carbon emission controls. Environ. Health Perspect. 120, 831-839.

Bian, C., Jiang, W., Greatbatch, R.J., 2013. An exploratory model study of sediment transport sources and deposits in the Bohai Sea, Yellow Sea, and East China Sea. J. Geophys. Res. 118, 5908-5923.

Bianchi, T.S., Allison, M.A., 2009. Large-river delta-front estuaries as natural "recorders" of global environmental change. Proc. Natl. Acad. Sci. U. S. A. 106, 8085-8092.

Bird, M.I., Wynn, J.G., Saiz, G., Wurster, C.M., McBeath, A., 2015. The pyrogenic carbon cycle. Annu. Rev. Earth Planet. Sci. 43, 273-298.

Bond, T.C., Streets, D.G., Yarber, K.F., Nelson, S.M., Woo, J.H., Klimont, Z., 2004. A technology-based global inventory of black and organic carbon emissions from combustion. J. Geophys. Res. 109, D14203.

Cao, J.J., Zhu, C.S., Tie, X.X., Geng, F.H., Xu, H.M., Ho, S., Wang, G.H., Han, Y.M., Ho, K.F. 2013. Characteristics and sources of carbonaceous aerosols from Shanghai, China. Atmos. Chem. Phys. 13, 803-817.

Chen, B., Andersson, A., Lee, M., Kirillova, E.N., Xiao, Q., Krusa, M., Shi, M., Hu, K., Lu, Z., Streets, D.G., Du, K., Gustafsson, O., 2013. Source forensics of black carbon aerosols from China. Environ. Sci. Technol. 47, 9102-9108.

Cong, Z., Kang, S., Gao, S., Zhang, Y., Li, Q., Kawamura, K., 2013. Historical trends of atmospheric black carbon on Tibetan Plateau as reconstructed from a 150-year lake sediment record. Environ. Sci. Technol. 47, 2579-2586.

Coppola, A.I., Wiedemeier, D.B., Galy, V., Haghipour, N., Hanke, U.M., Nascimento, G.S., Usman, M., Blattmann, T.M., Reisser, M., Freymond, C.V., Zhao, M., Voss, B., Wacker, L., Schefuß, E., Peucker-Ehrenbrink, B., Abiven, S., Schmidt, M.W.I., Eglinton, T.I. 2018. Global-scale evidence for the refractory nature of riverine black carbon. Nat Geosci. 1, 1-6.

DeMaster, D.J., McKee, B.A., Nittrouer, C.A., Jiangchu, Q., Guodong, C., 1985. Rates of sediment accumulation and particle reworking based on radiochemical measurements from continental shelf deposits in the East China Sea. Cont. Shelf Res. 4, 143-158.

Deng, B., Zhang, J., Wu, Y., 2006. Recent sediment accumulation and carbon burial in the East China Sea. Glob. Biogeochem. Cycles 20, 466-480.

Dickens, A.F., Gélinas, Y., Masiello, C.A., Wakeham, S., Hedges, J.I., 2004. Reburial of fossil organic carbon in marine sediments. Nature 427, 336-339.

Elmquist, M., Semiletov, I., Guo, L., Gustafsson, Ö., 2008. Pan-Arctic patterns in black carbon sources and fluvial discharges deduced from radiocarbon and PAH source apportionment markers in estuarine surface sediments. Glob. Biogeochem. Cycles 22, GB2018.

Fang, Y., Chen, Y., Tian, C., Lin, T., Hu, L., Huang, G., Tang, J., Li, J., Zhang, G., 2015. Flux and budget of $\mathrm{BC}$ in the continental shelf seas adjacent to Chinese high BC emission source regions. Glob. Biogeochem. Cycles 29, 957-972.

Fang, Y., Chen, Y., Tian, C., Lin, T., Hu, L., Li, J., Zhang, G., 2016. Application of PMF receptor model merging with PAHs signatures for source apportionment of black carbon in the continental shelf surface sediments of the Bohai and Yellow Seas, China. J. Geophys. Res. 121, 1346-1359.

Fang, Y., Chen, Y., Tian, C., Wang, X., Lin, T., Hu, L., Li, J., Zhang, G., Luo, Y., 2018. Cycling and budgets of organic and black carbon in coastal Bohai Sea, China: impacts of natura and anthropogenic perturbations. Glob. Biogeochem. Cycles 32, 971-986.

Flores-Cervantes, D.X., Plata, D.L., MacFarlane, J.K., Reddy, C.M., Gschwend, P.M., 2009. Black carbon in marine particulate organic carbon: inputs and cycling of highly recalcitrant organic carbon in the Gulf of Maine. Mar. Chem. 113, 172-181.

Guo, L., Semiletov, I., Gustafsson, Ö., Ingri, J., Andersson, P., Dudarev, O., White, D., 2004 Characterization of Siberian Arctic coastal sediments: implications for terrestrial organic carbon export. Glob. Biogeochem. Cycles 18, 1-10.

Gustafsson, Ö., Gschwend, P.M., 1998. The flux of black carbon to surface sediments on the New England continental shelf. Geochim. Cosmochim. Acta 62, 465-472.

Hammes, K., Schmidt, M.W.I., Smernik, R.J., Currie, L.A., Ball, W.P., Nguyen, T.H. Louchouarn, P., Houel, S., Gustafsson, Ö., Elmquist, M., Cornelissen, G., Skjemstad, J.O., Masiello, C.A., Song, J., Peng, P.A., Mitra, S., Dunn, J.C., Hatcher, P.G., Hockaday, W.C., Smith, D.M., Hartkopf-Fröder, C., Böhmer, A., Lüer, B., Huebert, B.J., Amelung, W., Brodowski, S., Huang, L., Zhang, W., Gschwend, P.M., Flores-Cervantes, D.X. Largeau, C., Rouzaud, J.-N., Rumpel, C., Guggenberger, G., Kaiser, K., Rodionov, A., Gonzalez-Vila, F.J., Gonzalez-Perez, J.A., de la Rosa, J.M., Manning, D.A.C., LópezCapél, E., Ding, L., 2007. Comparison of quantification methods to measure firederived (black/elemental) carbon in soils and sediments using reference materials from soil, water, sediment and the atmosphere. Glob. Biogeochem. Cycles 21 GB3016.

Han, Y.M., Cao, J.J., Chow, J.C., Watson, J.G., An, Z.S., Jin, Z.D., Fung, K., Liu, S.X., 2007a. Evaluation of the thermal/optical reflectance method for discrimination between charand soot-EC. Chemosphere 69, 569-574.

Han, Y.M., Cao, J.J., An, Z.S., Chow, J.C., Watson, J.G., Jin, Z.D., Fung, K., Liu, S.X., 2007b. Evaluation of the thermal/optical reflectance method for quantification of elemental carbon in sediments. Chemosphere 69, 526-533.
Han, Y.M., Cao, J.J., Yan, B.Z., Kenna, T.C., Jin, Z.D., Cheng, Y., Chow, J.C., An, Z.S., 2011. Comparison of elemental carbon in lake sediments measured by three different methods and 150-year pollution history in eastern China. Environ. Sci. Technol. 45, 5287-5293.

Han, Y., Marlon, J., Cao, J., Jin, Z., An, Z., 2012. Holocene linkages between char, soot, biomass burning and climate from Lake Daihai, China. Glob. Biogeochem. Cycles 26, GB4017.

Han, Y.M., Bandowe, B.A.M., Wei, C., Cao, J.J., Wilcke, W., Wang, G.H., Ni, H.Y., Jin, Z.D., An, Z.S., Yan, B.Z., 2015a. Stronger association of polycyclic aromatic hydrocarbons with soot than with char in soils and sediments. Chemosphere 119, 1335-1345.

Han, Y.M., Wei, C., Bandowe, B.A.M., Wilcke, W., Cao, J.J., Xu, B.Q., Gao, S.P., Tie, X.X., Li, G.H., Jin, Z.D., An, Z.S., 2015b. Elemental carbon and polycyclic aromatic compounds in a 150-year sediment Core from Lake Qinghai, Tibetan Plateau, China: influence of regional and local sources and transport pathways. Environ. Sci. Technol. 49, 4176-4183.

Hu, L. Lin, T., Shi, X. Yang, Z., Wang, H., Zhang, G., Guo, Z., 2011. The role of shelf mud depositional process and large river inputs on the fate of organochlorine pesticides in sediments of the Yellow and East China seas. Geophys. Res. Lett. 38, L03602.

Hu, L., Shi, X., Bai, Y., Fang, Y., Chen, Y., Qiao, S., Liu, S., Yang, G., Kornkanitnan, N., Khokiattiwong, S., 2016. Distribution, input pathway and mass inventory of black carbon in sediments of the Gulf of Thailand, SE Asia. Estuar. Coast. Shelf Sci. 170, 10-19.

Huang, L., Zhang, J., Wu, Y., Wang, J., 2016. Distribution and preservation of black carbon in the East China Sea sediments: perspectives on carbon cycling at continental margins. Deep-Sea Res. II Top. Stud. Oceanogr. 124, 43-52.

Hung, C., Gong, G., Ko, F., Lee, H., Chen, H., Wu, J., Hsu, M., Peng, S., Nan, F., Santschi, P., 2011. Polycyclic aromatic hydrocarbons in surface sediments of the East China Sea and their relationship with carbonaceous materials. Mar. Pollut. Bull. 63, 464-470.

Jia, J., Gao, J., Cai, T., Li, Y., Yang, Y., Wang, Y.P., Xia, X., Li, J., Wang, A., Gao, S., 2018. Sediment accumulation and retention of the Changjiang (Yangtze River) subaqueous delta and its distal muds over the last century. Mar. Geol. 401, 2-16.

Jiang, Y., Lin, T., Wu, Z., Li, Y., Li, Z., Guo, Z., Yao, X., 2018. Seasonal atmospheric deposition and air-sea gas exchange of polycyclic aromatic hydrocarbons over the Yangtze River Estuary, East China Sea: implications for source-sink processes. Atmos. Environ. 178, 31-40.

Jurado, E., Dachs, J., Duarte, C.M., Simó, R., 2008. Atmospheric deposition of organic and black carbon to the global oceans. Atmos. Environ. 42, 7931-7939.

Khan, A.J., Swami, K., Ahmed, T., Bari, A., Shareef, A., Husain, L., 2009. Determination of elemental carbon in lake sediments using a thermal-optical transmittance (TOT) method. Atmos. Environ. 43, 5989-5995.

Lehndorff, E., Roth, P.J., Cao, Z.H., Amelung, W., 2014. Black carbon accrual during 2000 years of paddy-rice and non-paddy cropping in the Yangtze River Delta, China. Glob. Chang. Biol. 20, 1968-1978.

Li, X., Bianchi, T.S., Allison, M.A., Chapman, P., Mitra, S., Zhang, Z., Yang, G., Yu, Z., 2012. Composition, abundance and age of total organic carbon in surface sediments from the inner shelf of the East China Sea. Mar. Chem. 145-147, 37-52.

Lin, T., Hu, L., Guo, Z., Zhang, G., Yang, Z., 2013. Deposition fluxes and fate of polycyclic aromatic hydrocarbons in the Yangtze River estuarine-inner shelf in the East China Sea. Glob. Biogeochem. Cycles 27, 77-87.

Liu, J., Li, A., Xu, K., Velozzi, D., Yang, Z., Milliman, J., DeMaster, D., 2006. Sedimentary features of the Yangtze River-derived along-shelf clinoform deposit in the East China Sea. Cont. Shelf Res. 26, 2141-2156.

Liu, J., Xu, K., Li, A., Milliman, J., Velozzi, D., Xiao, S., Yang, Z., 2007. Flux and fate of Yangtze River sediment delivered to the East China Sea. Geomorphology 85, 208-224.

Liu, W., Hu, L., Lin, T., Li, Y., Guo, Z., 2017a. Distribution and mass inventory of mercury in sediment from the Yangtze River estuarine-inner shelf of the East China Sea. Cont. Shelf Res. 132, 29-37.

Liu, Z., Lu, X., Feng, J., Fan, Q., Zhang, Y., Yang, X., 2017b. Influence of ship emissions on urban air quality: a comprehensive study using highly time-resolved online measurements and numerical simulation in Shanghai. Environ. Sci. Technol. 51, 202-211.

Lohmann, R., Bollinger, K., Cantwell, M., Feichter, J., Fischer-Bruns, I., Zabel, M., 2009. Fluxes of soot black carbon to South Atlantic sediments. Glob. Biogeochem. Cycles 23, GB1015.

Masiello, C.A., 2004. New directions in black carbon organic geochemistry. Mar. Chem. 92, 201-213.

Ramanathan, V., Carmichael, G., 2008. Global and regional climate changes due to black carbon. Nat. Geosci. 1, 221-227.

Sánchez-García, L., Cato, I., Gustafsson, Ö., 2012. The sequestration sink of soot black carbon in the Northern European Shelf sediments. Glob. Biogeochem. Cycles 26, GB1001.

Sánchez-García, L., de Andrés, J.R., Gélinas, Y., Schmidt, M.W.I., Louchouarn, P., 2013. Different pools of black carbon in sediments from the Gulf of Cádiz (SW Spain): method comparison and spatial distribution. Mar. Chem. 151, 13-22.

Smith, D.M., Griffin, J.J., Goldberg, E.D., 1973. Elemental carbon in marine sediments: a baseline for burning. Nature 241, 268-270.

Suman, D.O., Kuhlbusch, T., Lim, B., 1997. Marine sediments: a reservoir for black carbon and their use as spatial and temporal records of combustion. In: Clark, J.S., Cachier, H., Goldammer, J.G., Stocks, B. (Eds.), Sediment Records of Biomass Burning and Global Change. Springer, Berlin, pp. 271-293.

Wang, H., Yang, Z., Saito, Y., Liu, J.P., Sun, X., Wang, Y., 2007. Stepwise decreases of the Huanghe (Yellow River) sediment load (1950-2005): impacts of climate change and human activities. Glob. Planet. Chang. 57, 331-354.

Wang, R., Tao, S., Wang, W., Liu, J., Shen, H., Shen, G., Wang, B., Liu, X., Li, W., Huang, Y., 2012. Black carbon emissions in China from 1949 to 2050. Environ. Sci. Technol. 46, 7595-7603.

Wang, F., Guo, Z., Lin, T., Hu, L., Chen, Y., Zhu, Y., 2015. Characterization of carbonaceous aerosols over the East China Sea: the impact of the East Asian continental outflow. Atmos. Environ. 110, 163-173. 
Wang, X., Xu, C., Druffel, E.R.M., Xue, Y., Qi, Y., 2016. Two black carbon pools transported by the Changjiang and Huanghe Rivers in China. Glob. Biogeochem. Cycles 30, $1778-1790$.

Xu, C., Xue, Y., Qi, Y., Wang, X., 2016. Quantities and fluxes of dissolved and particulate black carbon in the Changjiang and Huanghe Rivers, China. Estuar. Coasts 39, 1617-1625.

Xu, W., Wang, F., Li, J., Tian, L., Jiang, X., Yang, J., Chen, B., 2017. Historical variation in black carbon deposition and sources to Northern China sediments. Chemosphere 172 $242-248$.

Yang, W., Guo, L., 2018. Sources and burial fluxes of soot black carbon in sediments on the Mackenzie, Chukchi, and Bering Shelves. Cont. Shelf Res. 155, 1-10.

Yang, Z., Wang, H., Saito, Y., Milliman, J.D., Xu, K., Qiao, S., Shi, G., 2006. Dam impacts on the Changjiang (Yangtze) river sediment discharge to the sea: the past 55 years and after the Three Gorges Dam. Water Resour. Res. 42, W04407.
Zhang, J., Guo, X., Zhao, L., Miyazawa, Y., Sun, Q., 2017. Water exchange across isobaths over the continental shelf of the East China Sea. J. Phys. Oceanogr. 47, 1043-1060.

Zhang, F., Chen, Y., Chen, Q., Feng, Y., Shang, Y., Yang, X., Gao, H., Tian, C., Li, J., Zhang, G. Matthias, V., Xie, Z., 2018. Real-world emission factors of gaseous and particulate pollutants from marine fishing boats and their total emissions in China. Environ. Sci. Technol. 52, 4910-4919.

Zhu, C., Wang, Z., Xue, B., Yu, P., Pan, J., Wagner, T., Pancost, R., 2011. Characterizing the depositional settings for sedimentary organic matter distributions in the Lower Yangtze River-East China Sea shelf system. Estuar. Coast. Shelf Sci. 93, 182-191. 